\title{
PENERAPAN STANDAR AKUNTANSI KEUANGAN ENTITAS MIKRO KECIL DAN MENENGAH PADA USAHA KECIL DAN MENENGAH (Studi pada Pengusaha Keramik dan Craft Plered - Purwakarta)
}

\author{
Yane Devi Anna \\ yane.devi@ekuitas.ac.id \\ Lilis Saidah \\ lilissaidah2026@yahoo.com \\ Dita Rari Dwi R.T \\ dita.raridwi@ekuitas.ac.id
}

\section{SEKOLAH TINGGI ILMU EKONOMI EKUITAS}

\begin{abstract}
ABSTRAK
Kegiatan pengabdian masyarakat dilakukan pada pengrajin keramik di Desa Anjun Kecamatan Plered Purwakarta bertujuan untuk membantu dalam menyusun laporan keuangan berdasarkan Standar Akuntansi Keuangan Entitas Mikro Kecil dan Menengah. Kegiatan ini dimulai dengan membantu dalam memperbaiki bukti transaksi, proses pencatatan transaksi sampai dengan penyusunan laporan keuangan serta membantu dalam perhitungan pajak. Metode yang digunakan yakni melalui pelatihan dan pendampingan dalam membuat dokumen transaksi, penyusunan laporan keuangan, baik secara manual maupun menggunakan software akuntansi berbasis excel; serta pembekalan pelatihan penghitungan pajak. Hasil yang diperoleh dari kegiatan ini diantaranya berupa bukti transaksi serta manual book terkait siklus akuntansi serta penggunaan software akuntansi berbasis excel sederhana yang diharapkan dapat membantu para perajin keramik dalam penyusunan laporan keuangan serta penghitungan pajak usahanya.
\end{abstract}

Kata kunci: Laporan Keuangan, Entitas Mikro Kecil dan Menengah, Standar Akuntansi Keuangan.

\section{PENDAHULUAN}

Pengusaha keramik dan craft merupakan bentuk usaha kecil menengah yang bergerak di bidang industri pembuatan kerajinan keramik, berupa keramik hias yang produknya berupa benda hias untuk elemen interior seperti guci, vas, piring, dan lainlain untuk pasar lokal dan ekspor. Selain itu, produk yang dihasilkan oleh pengusaha craft sebagian besar berupa cinderamata/souvenir disamping produk benda hias untuk elemen interior seperti vas, table top, dan lain-lain.

Pemasaran produk yang dihasilkan tersebut tersebar di beberapa art shop di kota-kota yang sering dikunjungi oleh turisturis asing, seperti Jogjakarta, Bali, Jakarta, Bandung, Surabaya, dan kota-kota besar lainnya. Selain itu para pengusaha keramik dan craft Plered telah melakukan pemasaran produk melalui ekspor ke negara Amerika, Eropa dan beberapa negara Asia seperti 
Korea, Jepang, dan lain-lain. Sejak tahun 2013, melalui penambahan sarana dan prasarana produksinya, para pengusaha keramik berhasil menambah tujuan negara ekspor secara mandiri seperti ke Brasil, Chili, Cekoslovakia, Rusia dan Inggris.

Berdasarkan kondisi usaha kerajinan keramik hias saat ini, para pengusaha keramik, memiliki omset penjualan rata-rata sebesar Rp 590.000.000,- setiap tahunnya. Omset tersebut diperoleh dari penjualan untuk wilayah lokal dan mancanegara. Sedangkan pengusaha craft berdasarkan kondisi usaha kerajinan keramik hias saat ini, memiliki omset penjualan rata-rata sebesar Rp 223.333.000,- setiap tahunnya. Omset tersebut sebagian besar diperoleh dari penjualan untuk wilayah lokal. Namun sejak satu tahun terakhir ini ditambah dengan penjualan ke mancanegara melalui kegiatan ekspor. Dilihat dari segi omset per tahunnya serta didasarkan pada UndangUndang Nomor 20 Tahun 2008 tentang usaha Mikro, Kecil, dan Menengah (UMKM), maka pengusaha keramik termasuk dalam kelompok usaha kecil dengan omset per tahunnya antara 300 juta sampai 2,5 milyar. Sedangkan pengusaha craft tergolong ke dalam jenis usaha mikro dengan omset per tahunnya berada di antara 50 juta sampai 300 juta (UU no 20 tahun 2008).

Pada tahun 2018, Ikatan Akuntan Indonesia (IAI) telah mengeluarkan Standar Akuntansi Keuangan Entitas Mikro, Kecil dan Menengah (EMKM) sebagai pedoman untuk penyajian Laporan Keuangan bagi pengusaha Mikro, Kecil dan Menengah. Terkait dengan hal tersebut, para pengusaha keramik dan craft Plered masih mengalami kesulitan dalam penyajian laporan keuangan. Sedangkan. saat ini bukti transaksi yang digunakan baru berupa bukti untuk penjualan barang saja, belum bernomor urut cetak, dan belum adanya bukti pengeluaran kas yang memadai, serta pengarsipan dokumen transaksi yang belum tersusun rapi. Pencatatan yang dilakukan hanya sebatas kas masuk dan kas keluar.
Selain itu, pencatatan keuangan belum mengelompokkan traznsaksi berdasarkan akun-akunnya (aset, kewajiban, modal, pendapatan, dan beban) sehingga agak kesulitan untuk dapat mengetahui dengan pasti berapa aset yang dimiliki oleh pengusaha keramik dan craft (Kieso, 2015).

Dengan melihat permasalahan yang dihadapi para pengusaha keramik dan craft Plered, maka kegiatan pengabdian masyarakat ini dilakukan dengan tujuan untuk membantu para pengusaha keramik agar dapat menyajikan laporan keuangan berdasarkan SAK EMKM yang berlaku per 1 Januari 2018. Adapun hasil yang diharapkan dari kegiatan pengabdian ini, antara lain:

1) Jasa

a) Pendampingan dalam penyiapan bukti transaksi.

b) Pelatihan siklus akuntansi disertai dengan pendampingan selama 1 (satu) bulan.

c) Pendampingan dalam penerapan software akuntansi berbasis excel dalam pencatatan transaksi keuangan bagi para pengusaha keramik dan praft selama 3 (tiga) bulan.

2) Produk

a) Bukti transaksi dengan pengendalian internal yang lebih baik.

b) Modul berupa manual book mengenai siklus akuntansi.

c) Modul berupa manual book penggunaan software Excel secara sederhana yang telah disesuaikan dengan transaksi para pengusaha keramik.

d) Modul berupa manual book berkaitan dengan materi cara penghitungan pajak untuk industri yang dijalankan. 


\section{METODE PELAKSANAAN}

Metode pelaksanaan kegiatan ini, dilakukan melalui kegiatan pelatihan dan pendampingan. Kegiatan ini dimulai dari menyiapkan bukti transaksi, siklus akuntansi, perpajakan sampai menggunakan software akuntansi berbasis excel. Kegiatan pendampingan dilakukan setelah pelatihan selesai dilaksanakan.

Adapun media yang digunakan dalam pelatihan yakni berupa modul. kegiatan pendampingan dengan perencanaan pelaksanaan selama 3 (tiga) bulan. Untuk siklus akuntansi akan disesuaikan dengan Standar Akuntansi Keuangan bagi Entitas Mikro, Kecil dan Menengah. Sedangkan pelatihan perpajakan akan disesuaikan dengan peraturan perpajakan yang terbaru.

Perancangan software akuntansi dilakukan untuk memberikan pemahaman terhadap sistem informasi akuntansi yang sederhana (Hall, 2016). Dari mulai menganalisis transaksi, membuat nomor akun, mengklasifikasikan transaksi sampai dengan penyusunan laporan keuangan. Langkah tersebut dilakukan dengan memberikan pedoman pencatatan atau kebijakan pencatatan keuangan sekaligus memberikan pelatihan dalam mengaplikasikan software akuntansi berbasis excel.

Kegiatan secara rinci terkait metode pelaksanaan adalah sebagai berikut:

a) Memberi pendampingan dalam menyiapkan bukti transaksi yang lebih baik serta pengarsipan dokumen transaksi yang memadai.

b) Memberikan penjelasan dan pelatihan terkait cara melakukan pencatatan keuangan hingga pembuatan laporan keuangan sehingga memudahkan para pengusaha keramik dalam pengambilan keputusan terkait dengan keuangan perusahaan berdasarkan SAK EMKM yang berlaku. c) Memberikan pelatihan cara penghitungan pajak terkait dengan pajak industri yang dijalankan.

d) Merancang manual book dan software akuntansi berbasis excel yang sederhana guna membantu perusahaan dalam penyajian laporan akuntansi terkait dengan laporan keuangan yang lebih akurat dan handal.

\section{HASIL DAN LUARAN}

Kegiatan pengabdian pada masyarakat yang dilakukan, dimulai pada bulan Maret sampai dengan bulan Juli 2018 yang terbagi dalam beberapa tahap:

\section{a) Tahap Pertama: Mengamati Proses Produksi}

Kegiatan ini dilakukan pada bulan Maret 2018. Adapun tujuan dari kegiatan ini adalah untuk mengamati proses produksi serta mengindentifikasi apa saja yang masuk ke dalam komponen harga pokok produksi, di mana hasil pengamatan tersebut terkait dengan pembuatan akun bagi perusahaan serta pembuatan format dalam laporan keuangan yang akan $m$

Proses produksi yang dilakukan oleh pengusaha keramik dan craft Plered dibagi menjadi dua, ada yang berdasarkan pesanan, dimana produksi yang berdasarkan pesanan sebagian besar adalah barang yang diekspor. Selain berdasarkan pesanan, para pengusaha memproduksi untuk dijual di showroom mereka. Berdasarkan proses produksi tersebut, maka para pengusaha perlu membuat laporan yang spesifik per order, sehingga mereka memerlukan laporan laba rugi per order yang mereka terima untuk melihat keuntungan yang diperoleh setiap order yang diterima.

Pada tahap ini hasil yang diperoleh berupa informasi terkait proses produksi dan biaya produksi yang digunakan oleh perusahaan. 


\section{b) Tahap Kedua: Pengamatan Pencatatan Transaksi}

Kegiatan ini dilaksanakan pada bulan April 2018. Pengamatan dilakukan melalui wawancara secara perorangan kepada pengusaha keramik dan craft, karena setiap pengusaha melakukan pencatatan yang berbeda-beda. Kegiatan ini bertujuan untuk memperoleh:

a. Informasi mengenai bukti transaksi, bukti apa saja yang digunakan dalam kegiatan transaksi sehari-hari baik dokumen yang dikeluarkan sebagai penjual maupun dokumen yang diterima sebagai pembeli bahan baku ataupun dokumen yang terkait dengan order yang mereka terima termasuk transaksi dalam mengekspor barang yang mereka produksi.

b. Pencatatan transaksi Para pengusaha yang mengikuti pelatihan terdiri dari kategori usaha mikro dan menengah sehingga pencatatan berbeda-beda, ada yang masih sangat sederhana namun ada pula yang sudah mencatat menggunakan komputer. Pencatatan yang dilakukan hanya sebatas arus kas masuk dan keluar saja, belum mencerminkan pencatatan transaksi berdasarkan prinsip akuntansi yang berlaku umum.

c. Informasi perpajakan, walau tidak semua namun ada beberapa pengusaha terutama yang sudah masuk kategori menengah dimana pajak merupakan salah satu yang kurang mereka pahami. Pada kegiatan ini, kami melakukan identifikasi atas transaksi mana yang terkait dengan pajak sehingga akan menjadi informasi dalam penyusunan modul dan software yang akan kami rancang.

Hasil yang diperoleh pada tahap ini adalah contoh bukti transaksi yang dibutuhkan terkait usaha yang dijalankan serta manual book terkait siklus akuntansi m pencatatan dan pembuatan laporan keuangan. c) Tahap Ketiga: Pelatihan Akuntansi dan Perpajakan

Setelah mendapatkan informasi kegiatan operasional maupun informasi yang berkaitan dengan penyiapan laporan keuangan, maka kegiatan selanjutnya adalah pelatihan akuntansi dan perpajakan yang diselengarakan pada bulan Mei 2018. Ada dua kegiatan utama yang kami lakukan:

a. Penjelasan mengenai bagaimana proses penyusunan laporan keuangan berdasarkan Standar Akuntansi Keuangan Entitas Mikro Kecil dan Menengah (SAK EMKM) dan perpajakan yang diakhiri dengan tanya jawab. Para pengusaha keramik dan craft Plered wajib mengimplementasikan standar tersebut karena usaha mereka termasuk ke dalam kriteria yang wajib menyajikan laporan keuangan berdasarkan standar tersebut.

b. Pratik penyusunan laporan keuangan. Dalam praktik ini, para peserta diberikan modul penyusunan laporan keuangan yang kami siapkan dari mulai menganalisis transaksi, menjurnal, memposting ke buku besar sampai dengan menyusun laporan keuangan.

Adapun hasil yang diperoleh pada tahap ini adalah berupa modul terkait tata cara pencatatan transaksi keuangan berdasarkan SAK EMKM sebagai panduan bagi pengusaha keramik Plered untuk menyusun laporan keuangannya.

d) Tahap Keempat: Pelatihan Software Akuntansi

Pelatihan software akuntansi dilaksanakan setelah pelatihan pengerjaan modul penyajian laporan keuangan secara manual. Hal tersebut dilakukan untuk memastikan para pengusaha keramik dan craft telah memahami tentang bagaimana proses penyusunan dan penyajian laporan keuangan. Software dirancang sesuai dengan informasi yang kami peroleh dari hasil survey pendahuluan sehingga sesuai dengan kebutuhan para pengusaha. 
Software akuntansi yang dibuat, terdiri dari beberapa bagian. Bagian pertama adalah data Chart of Account (COA), yang berisi daftar dan kode akun yang digunakan oleh pengusaha keramik dan craft Plered. Bagian kedua adalah pencatatan yang terdiri dari jurnal umum, buku besar, dan buku besar pembantu, yang digunakan untuk menginput berbagai macam data transaksi yang terjadi. Program ini didesain secara otomatis, sehingga input hanya terjadi para modul pencatatan. Bagian selanjutnya yaitu pelaporan yang terdiri dari neraca, laporan laba rugi, dan perubahan ekuitas, yang akan terbentuk secara otomatis. Laporan keuangan yang disusun telah disesuaikan dengan SAK EMKM. Bagian terakhir berisi tentang rasio keuangan, grafik penjualan, dan stok barang.

Pada tahap ini dihasilkan software akuntansi sederhana untuk industri kecil dan menengah guna membantu pengusaha dalam proses penyusunan laporan keuangan yang terkomputerisasi.

e) Tahap Kelima: Pendampingan dan Konsultasi

Kegiatan terakhir dalam pengabdian masyarakat adalah kegiatan pendampingan dan konsultasi yang dilaksanakan selama bulan Juni 2018. Para pengusaha menerapkan bagaimana menyusun dan menyajikan laporan keuangan berdasarkan SAK EMKM pada perusahaannya masingmasing baik secara manual ataupun menggunakan software. Beberapa pengusaha menyusun laporan keuangan secara manual sehingga masih sedikit yang menggunakan software, namun masih penyempurnaan yang disesuaikan dengan SAK EMKM.

\section{KESIMPULAN}

Kendala yang dihadapi oleh para pengusaha keramik adalah pencatatan yang dilakukan para pengusaha maupun pemahaman akuntansi dari para pengusaha di Plered yang berbeda-beda sehingga perlu dilakukan pelatihan dengan menggelompokan para pengusaha untuk memberikan pemahaman terkait dengan praktik akuntansi yang dibutuhkan, sehingga diharapkan para pengusaha mampu mengaplikasikannya d

Hasil dari pengabdian masyarakat ini adalah modul/manual book penyusunan laporan keuangan termasuk bagaimana perhitungan pajak dan format bukti transaksi serta software penyusunan pelaporan keuangan. Metode yang dilaksanakan dalam kegiatan ini adalah memberikan pelatihan dan latihan penyusunan laporan keuangan sesuai dengan operasional perusahaan dan diakhiri dengan pedampingan untuk memastikan para pengrajin dapat mengaplikasikannya. n SAK EMKM.

\section{DAFTAR PUSTAKA}

Hall, James. 2016. Sistem Informasi Akuntansi. Edisi Empat. Salemba Empat. Jakarta.

Ikatan Akuntan Indonesia, Standar Akuntansi Keuangan UMKM. Salemba Empat. Jakarta.

Kieso, D. E, Weygandt, J.J, and Warfield, T.D. 2015. Financial Accounting: IFRS Edition.Wiley.

Ningtyas, Jilma Dewi Ayu. 2017. Penyusunan Laporan Keuangan UMKM Berdasarkan Standar Akuntansi Keuangan Entitas Mikro, Kecil dan Menengah (Study Kasus Di UMKM Bintang Malam Pekalongan). Riset \& Jurnal Akuntansi, vol. 2 Nomor 1, Agustus. ISSN 2548-9224.

Pratiwi, Sariningtyas dan Tituk, Diah W. 2011. Standar Akuntansi Keuangan Entitas Tanpa Akuntabilitas Publik 
pada Usaha Kecil dan Menengah. Jurnal Akuntansi Keperilakuan Indonesia, 1 (1). pp. 90-101. ISSN $1475-1488$.

Riwayadi. 2014. Akuntansi Biaya Pendekatan Tradisional dan Kontemporer. Salemba Empat. Jakarta.

Rudiantoro, R. dan Siregar. 2011. Kualitas Laporan Keuangan UMKM serta Prospek Implementasi SAK ETAP. Simposium Nasionalx Akuntansi XVI. Aceh. 21-22 Juli. 